\title{
Typologie útvarů povrchových vod kategorie reka v prvním a druhém cyklu plánů povodí a její důsledky pro hodnocení stavu útvarů
}

\section{HANA PRCHALOVÁ, PETR VYSKOČ, SILVIE SEMERÁDOVÁ}

Klíčová slova: Rámcová směrnice o vodách - plán povodí - vodní útvar - typologie povrchových vod - ekologický stav

\section{SOUHRN}

Vymezení útvarů povrchových vod a určení jejich typologie patří k prvním krokům při implementaci Rámcové směrnice o vodě (dále RSV) [1]. První vymezení a určení typư v ČR proběhlo v letech 2004 a 2005 v rámci prvního cyklu plánů povodí, celý proces však byl významně přepracován v období 2009 až 2010 pro druhý cyklus. Cílem článku je porovnat postupy stanovení typologie v prvním a druhém cyklu plánů a ukázat důsledky změn, které ovlivňuji i základní nastavení ochrany povrchových vod.

\section{ÚVOD}

Určení typů útvarů povrchových vod je podle Rámcové směrnice o vodě jeden ze základů charakterizace oblastí povodí. Typy útvarů povrchových vod jsou zásadní pro určení dobrého ekologického stavu, kdy kvalita, struktura a funkce vodních ekosystémů spojených s povrchovými vodami jsou sice mírně ovlivněny antropogenními změnami, ale odlišuji se málo od nenarušených podmínek [2]. Nastavení

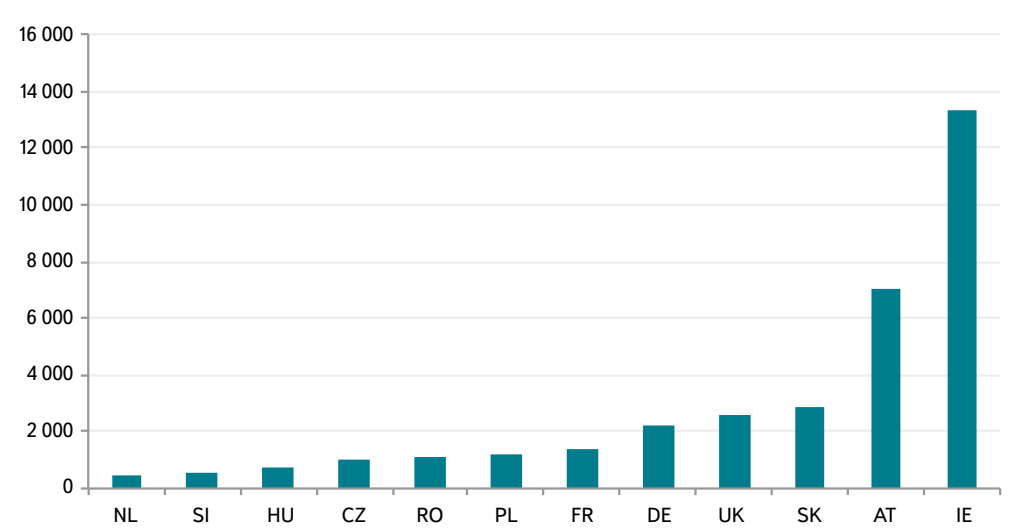

Obr. 1. Počet vymezených útvarů kategorie řeka v prvním cyklu plánů, přepočtený na plochu ČR (NL - Holandsko, SI - Slovinsko, HU - Mad’arsko, CZ - Česká republika, RO Rumunsko, PL - Polsko, FR - Francie, DE - Německo, UK - Velká Británie, SK - Slovenská republika, AT - Rakousko, IE - Irsko); zdroj dat: Eionet Central Data Repository Fig. 1. Number of delineated surface water bodies category river in the $1^{\text {st }}$ cycle of plans, recalculated to the area of CZ (NL - Netherlands, SI - United Kingdom, SK Slovakia, AT - Austria, IE - Ireland); data source: Eionet Central Data Repository typologie prímo určuje nastavení limitů dobrého ekologického stavu jak biologických složek, tak fyzikálně-chemické složky. Díky typologii mohou být stanoveny limity pro skupiny typů rozdílně. Podle směrnice se to sice týká všech kategorií povrchových vod (v prípadě ČR tedy řek a jezer), ale všechny české útvary kategorie jezero jsou bud' silně ovlivněné (což znamená, že pưvodně patřily k řekám, ale na základě vzniklých hydromorfologických modifikací se z nich staly nádrže či rybníky), nebo umělé (většinou zatopené vytěžené prostory na místech, kde se predtím žádný vodní útvar nevyskytoval). Pro tyto útvary se stanoví limity dobrého potenciálu, které ale více než na stanoveném typu závisí na zpưsobu užívání [3]. Z toho dưvodu je typologie v českých podmínkách zásadní pouze pro "prírozené" reky.

S typologií souvisí také vlastní vymezení útvarů povrchových vod - ideální situace je taková, kdy všechny útvary jsou z hlediska typologie homogenní. Zároveň ale není možné zvyšovat neúměrně počet vymezených útvarů, nebot pro každý útvar je potřeba hodnotit jeho ekologický a chemický stav či potenciál, což znamená mimo jiné značné požadavky na monitoring. Již v prvním cyklu plánů, připravovaných do konce roku 2009, se přístupy členských států významně lišily, např. Holandsko a Slovinsko vymezilo poměrně malý počet

Tabulka 1. Typologie podle systému A; zdroj dat: Rámcová směrnice o vodě Table 1. Typology under system A; data source: Water Framework Directive

\begin{tabular}{|c|c|}
\hline Pevná typologie & Popisné charakteristiky \\
\hline Ekoregion & Ekoregiony zakreslené v mapě A v př́loze XI \\
\hline \multirow{3}{*}{ Typ } & $\begin{array}{l}\text { Typologie nadmořské výšky: } \\
\text { — vysočina: > } 800 \text { m } \\
\text { — střední výška: } 200 \text { až } 800 \text { m } \\
\text { — nižina: < } 200 \text { m }\end{array}$ \\
\hline & $\begin{array}{l}\text { Typologie založená na velikosti } \\
\text { plochy povodí: } \\
\text { — malá: } 10 \text { až } 100 \text { km² } \\
\text { — střední: > } 100 \text { až } 1000 \text { km² } \\
\text { — velká: > } 1000 \text { až } 10000 \text { km² } \\
\text { — velmi velká: > } 10000 \text { km² }\end{array}$ \\
\hline & $\begin{array}{l}\text { Geologický typ: } \\
\text { — vápnitý } \\
\text { - křemitý } \\
\text { — organický }\end{array}$ \\
\hline
\end{tabular}




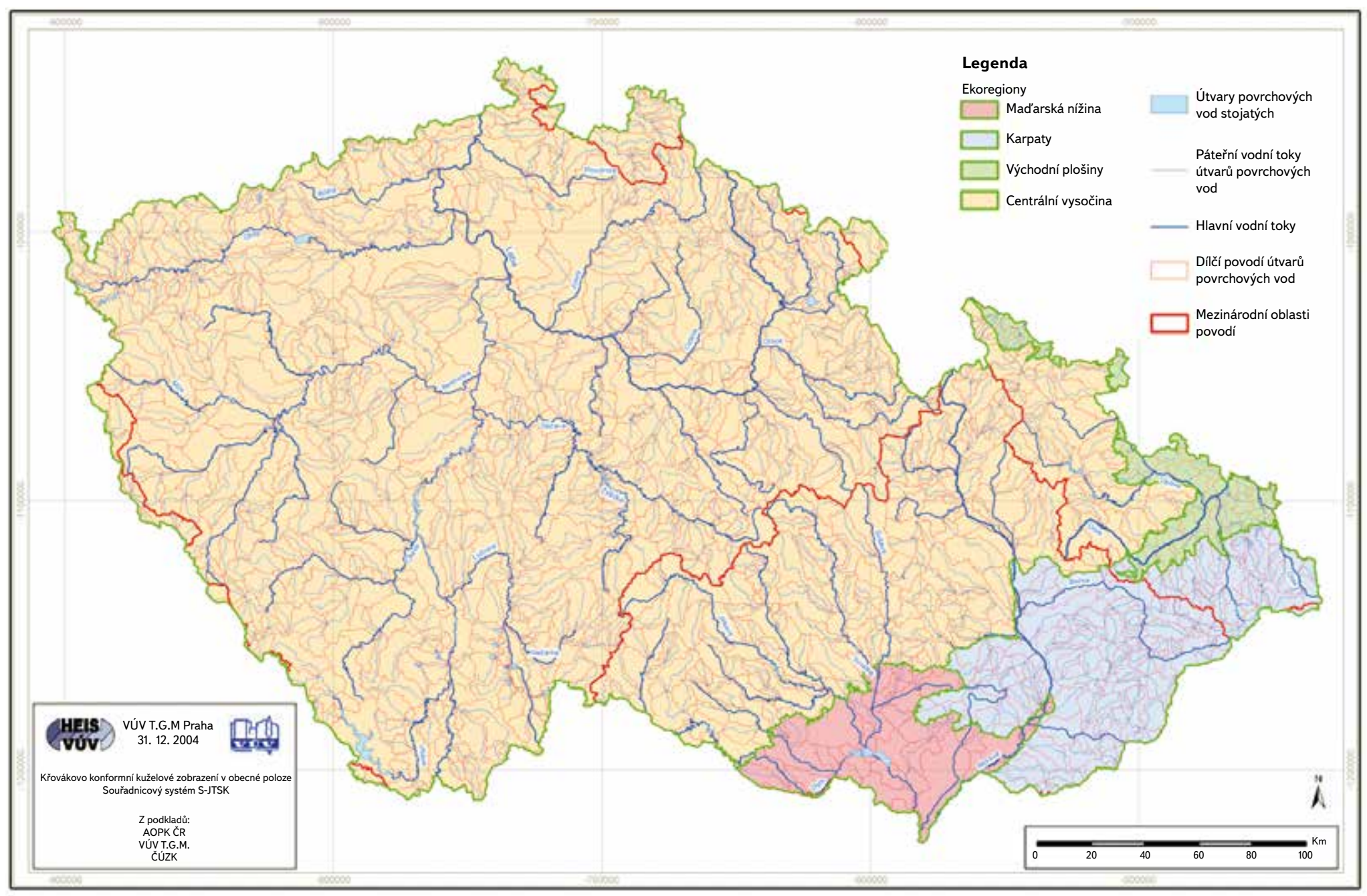

Obr. 2. Ekoregiony v ČR; zdroj dat: Charakterizace oblastí povodí (Zpráva 2005)

Fig. 2. Ecoregions in CR; data source: River Basin District Characterisation (Report 2005)

Tabulka 2. Typologie rek v prvním plánu; zdroj dat: Charakterizace oblastí povodí (Zpráva 2005)

Table 2. River typology in the $1^{\text {st }}$ plan; data source: River Basin District Characterisation (Report 2005)

ŘEKY

\begin{tabular}{|c|c|c|c|c|c|c|c|c|c|}
\hline \multicolumn{2}{|l|}{ Ekoregion } & \multicolumn{2}{|c|}{$\begin{array}{l}\text { Nadmořská výška - } \\
\text { uzávěrný profil (m n. m.) }\end{array}$} & \multicolumn{2}{|c|}{ Geologie } & \multicolumn{2}{|c|}{ Plocha povodí (km) } & \multicolumn{2}{|c|}{$\begin{array}{l}\text { Řád toku - } \\
\text { uzávěrný profil }\end{array}$} \\
\hline typ & kód & typ & kód & typ & kód & typ & kód & typ & kód \\
\hline Mad’arská nížina & 1 & $<200$ & 1 & křemitý & 1 & $<100$ & 1 & 4 & 4 \\
\hline Karpaty & 2 & $200-500$ & 2 & vápnitý & 2 & 100-1000 & 2 & 5 & 5 \\
\hline Východní plošiny & 3 & $500-800$ & 3 & & & $1000-10000$ & 3 & 6 & 6 \\
\hline \multirow[t]{2}{*}{ Centrální vysočina } & \multirow[t]{2}{*}{4} & \multirow[t]{2}{*}{$>800$} & \multirow{2}{*}{4} & & & $>10000$ & 4 & 7 & 7 \\
\hline & & & & & & & & 8 & 8 \\
\hline
\end{tabular}



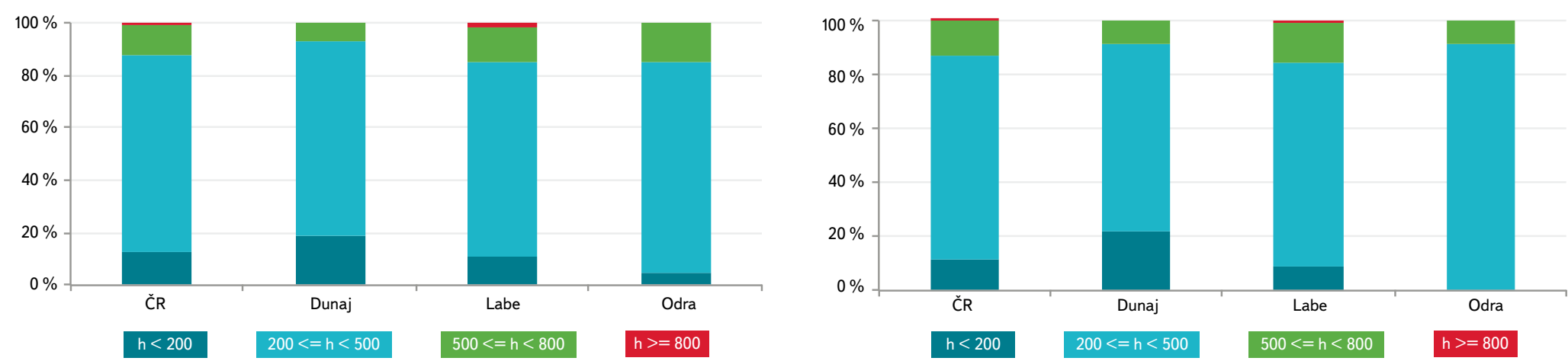

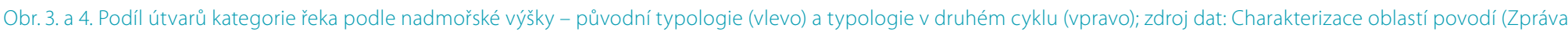
2005) a Reporting povodí 2016

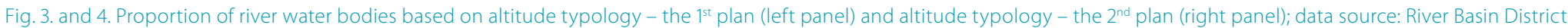
Characterisation (Report 2005) and River Basin Management Plans Reporting 2016

vodních útvarů/řek (při přepočtu na plochu ČR kolem 500), naopak Rakousko má kolem 7000 a Irsko dokonce 13000 útvarů kategorie řeka (obr. 1) [4]. Z tohoto hlediska se v ČR jak původní počet 1028 útvarů kategorie řeka, tak současný počet 1044 útvarů zdá jako celkem adekvátní, nicméně bude nutné počítat s určitou mírou nehomogenity mezi členskými státy.

\section{TYPOLOGIE V PRVNÍM A DRUHÉM CYKLU PLÁNU゚}

Vymezení vodních útvarů a stanovení jejich typů patří hned k prvním činnostem při prípravě plánů povodí. První vymezení útvarů kategorie řeka a jejich typologie [5] tak proběhlo do roku 2004 (společně s charakterizací a analýzou vlivů a dopadů).

Rámcová směrnice o vodě požaduje, aby při typologii byl použit bud' systém A (viz následující odstavec), který zároveň zahrnuje požadavek na minimální stupeň rozlišení, nebo je možné použít alternativní systém B (obsahující některé závazné a další volitelné faktory podle členských států). I v takovém príipadě by podle RSV členské státy měly předložit mapu s geografickými polohami typů shodných se stupněm rozlišení v systému A. První typologie byla založena na systému A s přidáním další charakteristiky, takže ve výsledku to byla kombinace systému A a B.
Systém A považuje za základní charakteristiku ekoregiony (rozložení ekoregionů v České republice je na obr. 2), dále nadmořskou výšku, velikost povodí a geologický typ (tabulka 1). V první typologii byla vzhledem k poloze ČR kategorie nadmořské výšky zjemněna (byla přidána nadmořská výška 500 m n. m.), v geologii byl na základě výsledků silikátové analýzy rozlišen vápnitý a křemitý typ (organický typ se v ČR prakticky nevyskytuje), plocha povodí byla převzata bez úprav a jako dodatečná charakteristika byl použit rád toku podle Strahlera. Výsledný typ byl tedy složen z několika kódů (tabulka 2). Tímto způsobem bylo v ČR vymezeno celkem 87 typů útvarů kategorie řeka [6].

$\checkmark$ druhém cyklu plánů bylo rozhodnuto, že musí být nově zpracována celá typologie a že podle ní budou nově převymezeny útvary povrchových vod.

Nová typologie [2] také vyšla ze systému A, ale jednak místo ekoregionů použila úmoří, nadmořská výška byla použita beze změny a velikost povodí byla vypuštěna. Faktory geologie a řádu toku sice zůstaly, jejich aplikace však byla značně jiná - $v$ prípadě geologie bylo konstatováno, že dělení geologie podle systému A je $v$ ČR nepoužitelné, vzhledem k neexistenci organického typu a zanedbatelnému rozsahu karbonátů, tudíž bylo doporučeno použít místo litologického hlediska strukturní dělení (typ metamorfity a vyvřeliny a druhý sedimenty a kvartér). Ve výsledku však byl použit typ krystalinikum a vulkanity a jako druhý pískovce, jílovce a kvartér.
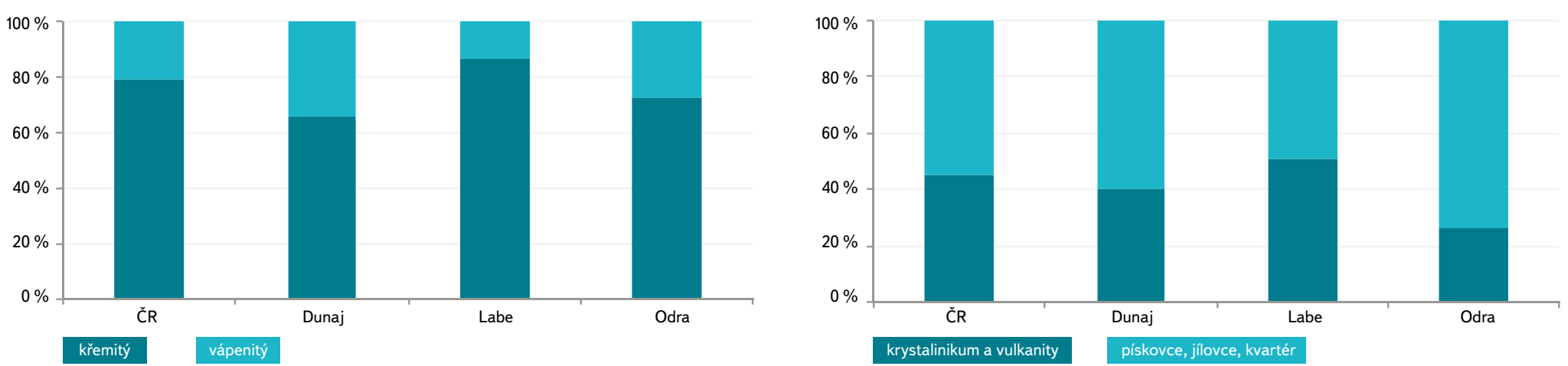

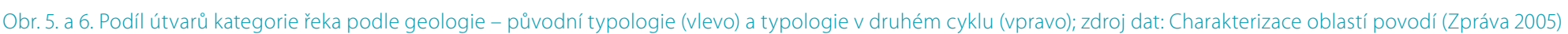
a Reporting povodí 2016

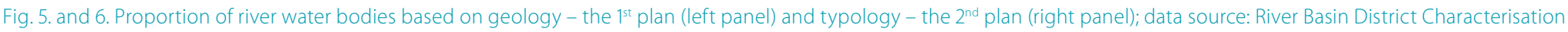
(Report 2005) and River Basin Management Plans Reporting 2016 

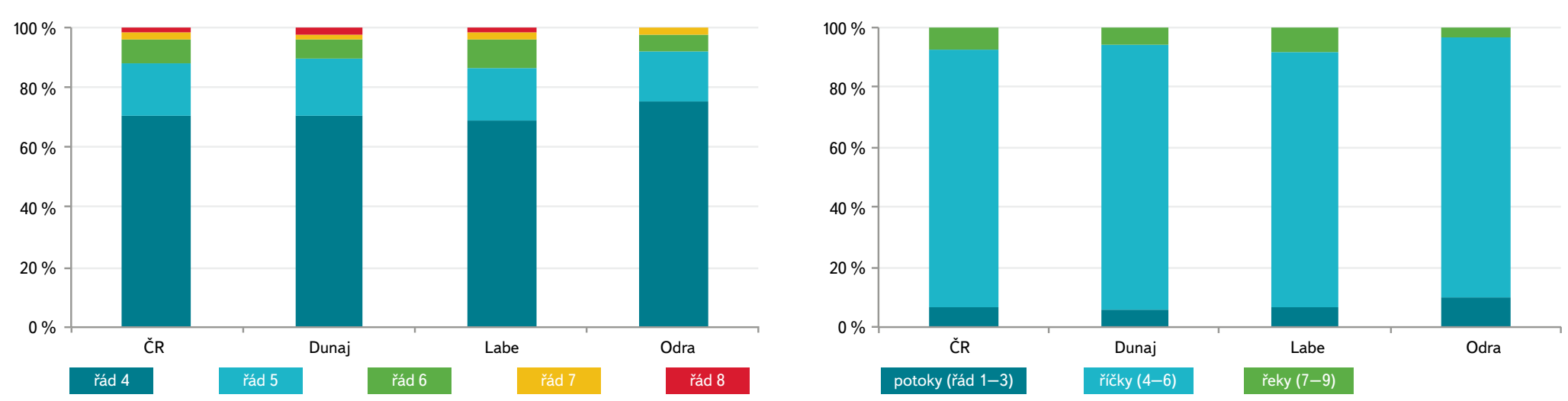

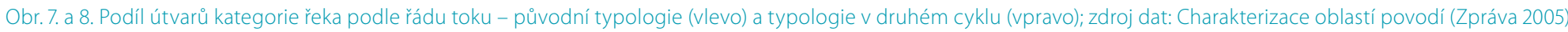
a Reporting povodí 2016

Fig. 7. and 8. Proportion of river water bodies based on Strahler orded - the $1^{\text {st }}$ plan (left panel) and typology - the $2^{\text {nd }}$ plan (right panel); data source: River Basin District Characterisation (Report 2005) and River Basin Management Plans Reporting 2016

Stejně tak bylo preděláno i rozdělení typů podle rádu toku (Strahlera) jednak byly řády znovu přepočteny podle mapy 1: 10000 (dřívější rozlišení bylo na podkladu mapy $1: 50000$ ), čímž bylo $\vee$ rádech dosaženo hodnoty 9 (pưvodně byly největší toky ráádu 8, nejmenší začínaly ráádem 4), a toky byly rozděleny do tři kategorií - rád 1-3, 4-6 a 7-9.

Počet deskriptorů typologie se tedy ve výsledku výrazně snižil a při aplikaci vzniklo pouze 35 typů (proti původním 87).

\section{POROVNÁNÍ VÝSLEDKŮ TYPOLOGIE V PRVNÍM A DRUHÉM CYKLU}

Porovnání výsledků typologie mezi prvním a druhým cyklem je možné udělat pouze omezeně, nebot zároveň se změnou typologie bylo významně prevymezeno cca 30 \% útvarů povrchových vod.

Volba úmoří, která jsou totožná s rozlišením národních oblastí povodí, místo ekoregionů znamenala značnou změnu v typologii. Jak je na obr. 2 zřejmé, podobnost mezi úmořím a ekoregiony je omezená. Zatímco Centrální vysočina je jediný ekoregion v oblasti povodí Labe, ale zasahuje i do zbylých dvou úmoří, tak národní části povodí Dunaje i Odry jsou při použití ekoregionů podrobněji rozdělené.

Nadmořská výška byla použita stejným zpưsobem a i přes změny ve vymezení útvarů povrchových vod je podíl útvarů v jednotlivých nadmořských výškách téměř totožný (obr. 3 a 4).

Naproti tomu přiřazení geologické charakteristiky vykazuje už značné rozdíly (obr. 5 a 6), což je dáno hlavně jiným pojetím geologických typů. Zatímco podíl křemitých typů je významnější, v druhé typologii mírně převažují pískovce, jílovce a kvartér (což ale neodpovídá geologickým poměrům v ČR).

Největší rozdíl však vznikl seskupením řádů tokư do tří kategorií v druhém cyklu proti původním pěti kategorím (obr. 7 a 8). Nově byla zařazena kategorie toků nižšího řádu (1-3), zatímco $v$ původní typologii začínaly útvary až od řádu 4. Zásadní rozdíl proti pưvodní typologii podle ráádu toků je, že drtivá většina toků ČR byla v druhém cyklu přiřazena k jediné kategorii.
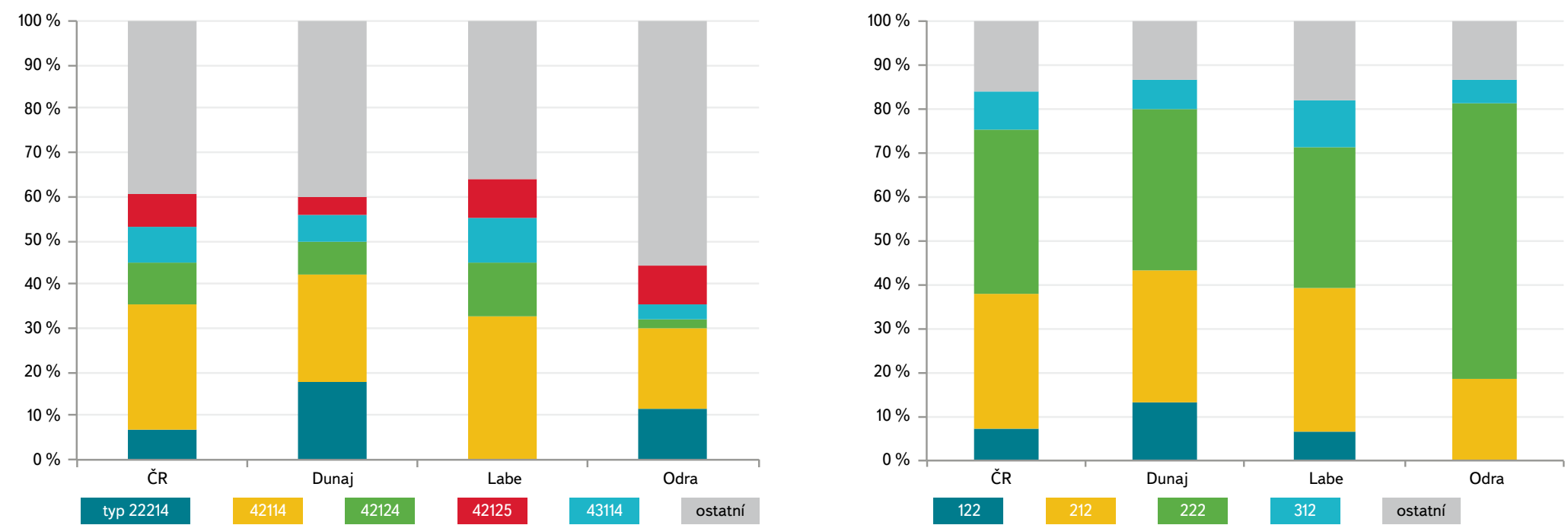

Obr. 9. a 10. Podíl nejčastěji se vyskytujících typů útvarů kategorie řeka podle původní typologie (vlevo) a typologie v druhém cyklu (vpravo); zdroj dat: Charakterizace oblastí povodí (Zpráva 2005) a Reporting povodí 2016

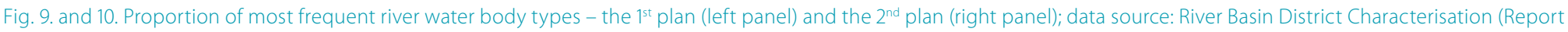
2005) and River Basin Management Plans Reporting 2016 

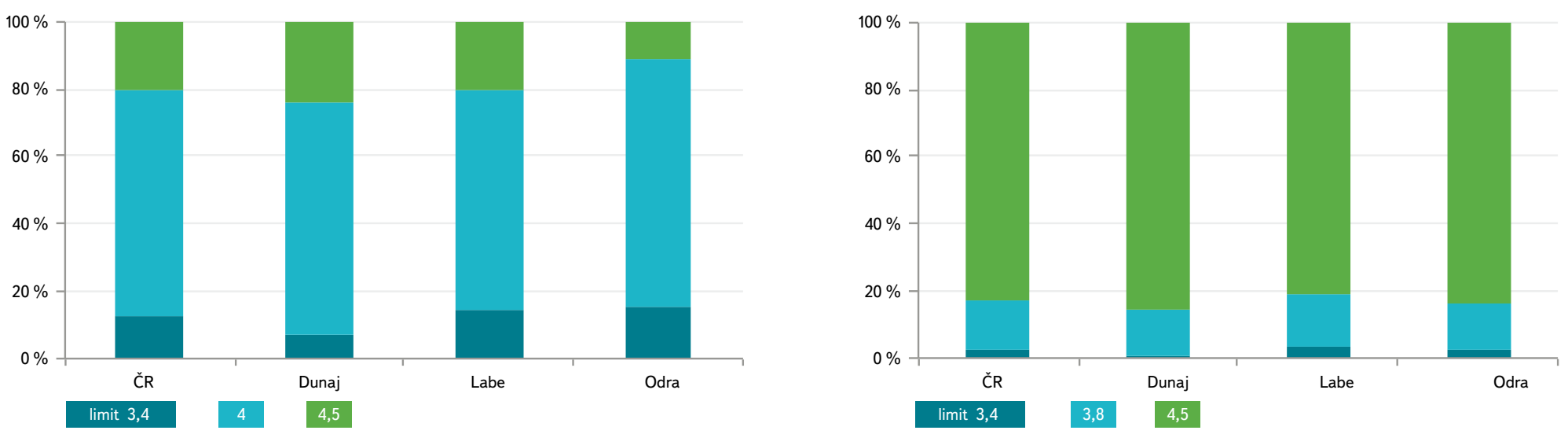

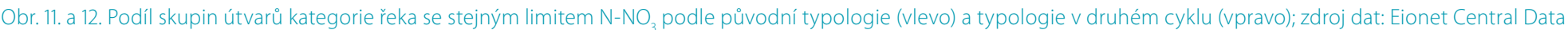
Repository a Reporting povodí 2016

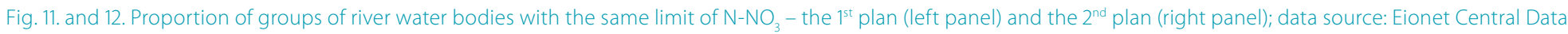
Repository and River Basin Management Plans Reporting 2016

Ve výsledku v prvním cyklu pět nejčetnějších typů tvořilo cca 60 \% všech útvarů, zatímco v druhém cyklu čtyři nejčastější typy tvoří 82-87 \% (obr. 9 a 10), úmoří zde není započítáno, nebot’ s výjimkou ryb nebylo použito pro rozlišení stavu složek ekologického stavu. V prvním cyklu byly 3 z 5 nejčastějších typů zařazeny do Centrální vrchoviny, křemitého typu, nadmořská výška 200-500 m a rád Strahlera 4 nebo 5, další typ se lišil pouze nadmořskou výškou 500-800 a poslední typ (znázorněný červeně) odpovídá ekoregionu Karpaty, nadmořská výška 200-500 m, rád toku 4 a vápnitý typ. V druhém cyklu všechny čtyřri nejčastější typy patři do řádu toku 4-6, dva patří do krystalinika a vulkanitů, zbylé dva do pískovců, jílovců a kvartéru a z hlediska nadmořské výšky patř́ jeden typ do nadmořské výšky méně než 200 m, dva 200-500 m a jeden 500-800 m n. m. Z grafu je ale ž̌ejmé, že typy 200-500 m n. m. (žlutá a zelená barva) výrazně v druhém cyklu dominují - celkem tvoří $67 \%$ všech útvarů; v prvním cyklu dominuje jen jeden typ (žlutý), patřící do Centrální vysočiny, nadmořské výšky 200-500 m n. m., ten ale tvoří pouze 18 \% všech útvarů na Odře a nejvíce 33 \% na Labi.

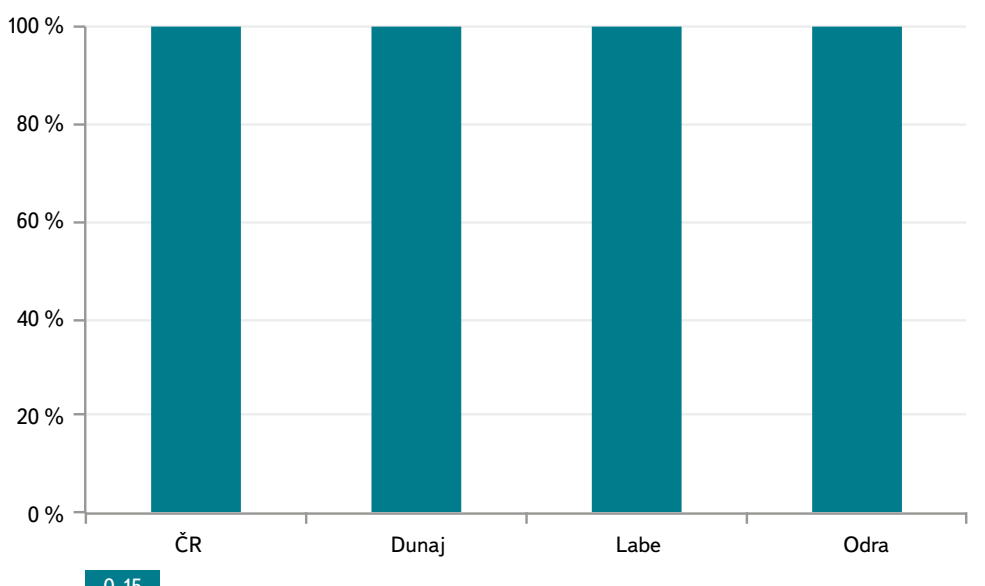

\section{DŮSLEDKY NASTAVENÍ TYPOLOGIE V PRVNIIM A DRUHÉM CYKLU PRO HODNOCENÍ STAVU}

Jak již bylo zmíněno, nastavení typologie je zásadní pro stanovení hranic velmi dobrého a dobrého stavu, a to pomocí definice referenčních podmínek. Použitá typologie musí být vhodná jak pro všechny relevantní biologické složky, tak pro všeobecné fyzikálně-chemické ukazatele. Vlastní stanovení typologie je abiotické, založené na expertních odhadech, proto je důležité typologii ověrit na biologických složkách.

Typologie pro řeky z prvního cyklu byla ověřena analýzou společenstev makrozoobentosu. Byl vyhodnocen soubor dostatečně podrobných dat reprezentujících 137 vodních útvarů zařazených do 43 typů (z 87 stanovených), které pokrývají 85 \% území ČR. Typologie byla i po biologickém ověření shledána vyhovující s tím, že príslušnost k povodí je významnější než príslušnost k ekoregionu. Zároveň však bylo zřejmé, že není možné ani praktické hledat typově specifické referenční podmínky pro všechny typy útvarů povrchových vod, proto se jako další krok některé vzácné typy sdružily do skupin př́buzných typů,

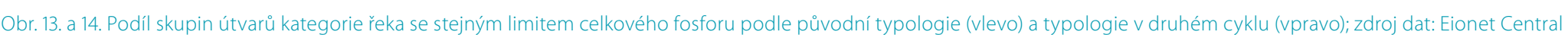
Data Repository a Reporting povodi 2016

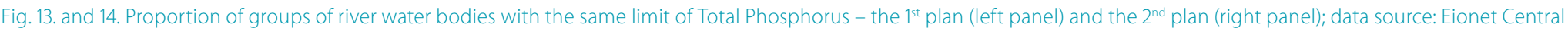
Data Repository and River Basin Management Plans Reporting 2016 
Tabulka 3. Hodnoty limitu dobrého stavu podle typu útvaru použité v prvním cyklu

Table 3. Values of good ecological status boundary for groups of water bodies - the pt $^{\text {st }} \mathrm{cle}$

\begin{tabular}{|c|c|c|c|c|c|c|}
\hline Ukazatel & $\begin{array}{l}\text { Charakteristická } \\
\text { hodnota }\end{array}$ & Limit & Jednotky & $\begin{array}{l}\text { Hodnota pro } \\
\text { skupinu } 1\end{array}$ & $\begin{array}{l}\text { Hodnota pro } \\
\text { skupinu } 2\end{array}$ & $\begin{array}{l}\text { Hodnota pro } \\
\text { skupinu } 3\end{array}$ \\
\hline Dusičnanový dusík & maximum & maximum & $\mathrm{mg} / \mathrm{l}$ & 3,4 & 4 & 4,5 \\
\hline Celkový fosfor & medián & maximum & $\mathrm{mg} / \mathrm{l}$ & 0,15 & & \\
\hline Rozpuštěný kyslík & medián & minimum & $\mathrm{mg} / \mathrm{l}$ & 9 & 8 & \\
\hline $\mathrm{BSK}_{5}$ & medián & maximum & $\mathrm{mg} / \mathrm{l}$ & 3 & 3,5 & 3,8 \\
\hline
\end{tabular}

Tabulka 4. Hodnoty limitu dobrého stavu podle typu útvaru použité v druhém cyklu

Table 4. Values of good ecological status boundary for groups of water bodies - the $2^{\text {nd }} \mathrm{cycle}$

\begin{tabular}{|c|c|c|c|c|c|c|c|}
\hline Ukazatel & $\begin{array}{l}\text { Charakteristická } \\
\text { hodnota }\end{array}$ & Limit & Jednotky & $\begin{array}{l}\text { Hodnota pro } \\
\text { skupinu } 1\end{array}$ & $\begin{array}{l}\text { Hodnota pro } \\
\text { skupinu } 2\end{array}$ & $\begin{array}{l}\text { Hodnota pro } \\
\text { skupinu } 3\end{array}$ & $\begin{array}{l}\text { Hodnota pro } \\
\text { skupinu } 4\end{array}$ \\
\hline Dusičnanový dusík & medián & maximum & $\mathrm{mg} / \mathrm{l}$ & 3,4 & 3,8 & 4,5 & \\
\hline Celkový fosfor & medián & maximum & $\mathrm{mg} / \mathrm{l}$ & 0,05 & 0,07 & 1 & 0,15 \\
\hline Rozpuštěný kyslík & medián & minimum & $\mathrm{mg} / \mathrm{l}$ & 11 & 10 & 9 & \\
\hline $\mathrm{BSK}_{5}$ & medián & maximum & $\mathrm{mg} / \mathrm{l}$ & 3 & 3,5 & 3,8 & \\
\hline
\end{tabular}

což ve výsledku znamenalo celkem 39 typů. Naopak byly také naplánovány nejfrekventovanější typy 42114, 42124 a 42125 (žluté, zelené a modré útvary kategorie řeka na obr. 9), které v ČR tvořily $45 \%$ všech útvarů a na Labi $55 \%$ útvarů, k rozdělení však už nedošlo. V rámci reportingu prvních plánů bylo pak vykázáno původních 87 typů.

Nově vytvořená typologie $\vee$ druhém cyklu $\vee$ souladu $s$ výsledky $\vee$ prvních plánech použila úmoří místo ekoregionů, zároveň však snižením počtu deskriptorů a kategorií došlo k tomu, že nejčastěji se vyskytující čtyři typy útvarů tvoří kolem 80 \% všech útvarů. Typologie byla testována na rybách, kdy se však nepotvrdila významnost geologie [7].

$\checkmark$ prvním cyklu nebyly k dispozici ověřené metodiky hodnocení biologických složek ani dostatek dat monitoringu, proto nelze použití typologie pro biologické složky hodnotit. Typologie byla využita pouze pro typově specifické podmínky všeobecných fyzikálně-chemických ukazatelů. Při zpracování

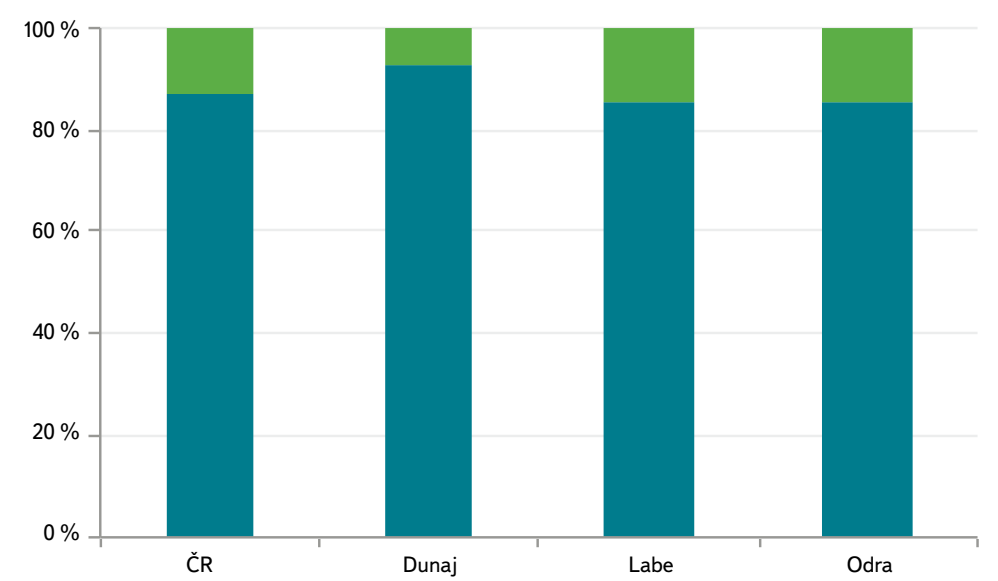

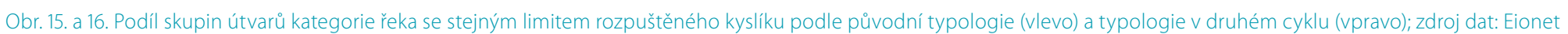
Central Data Repository a Reporting povodí 2016

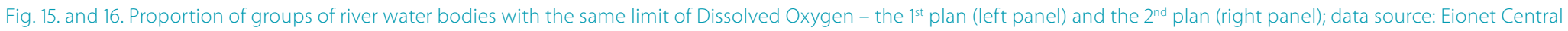
Data Repository and River Basin Management Plans Reporting 2016 

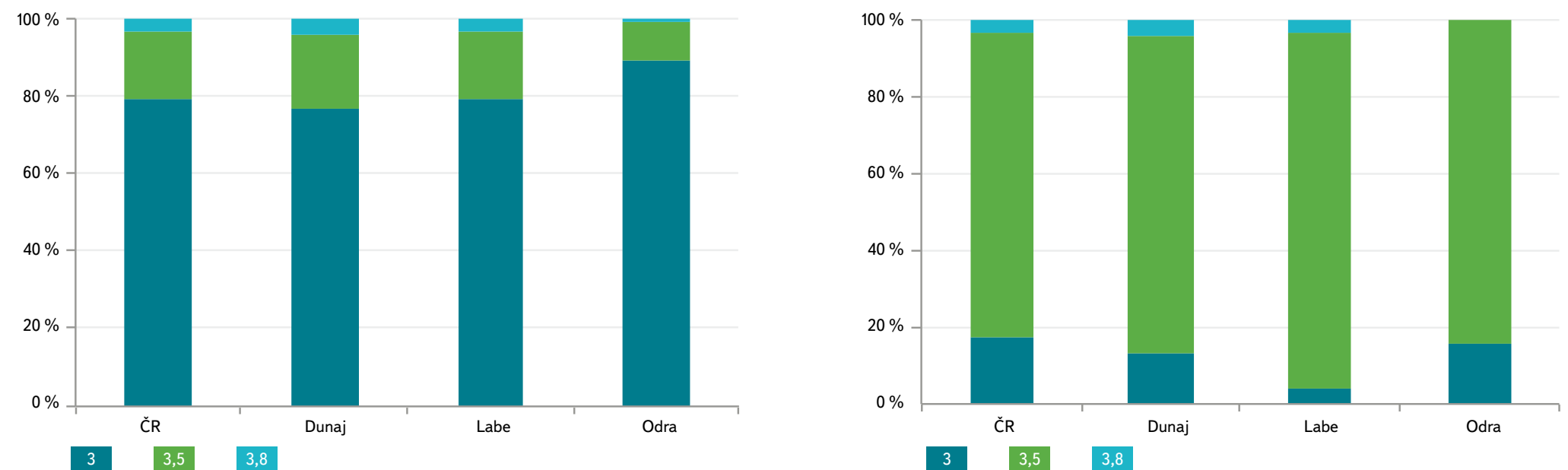

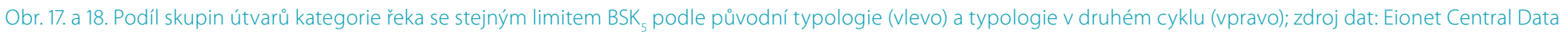
Repository a Reporting povodí 2016

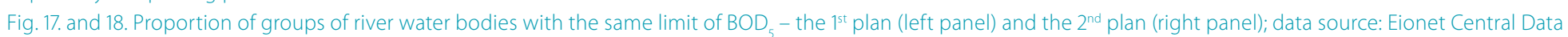
Repository and River Basin Management Plans Reporting 2016

metodik hodnocení jednotlivých složek ekologického stavu byla nově navržená typologie využita rưzným zpưsobem - v zásadě však pro biologické složky byly využity jen některé prvky typologie. Tak např. pro makrozoobentos a makrofyta byly pro rozlišení stavu použity pouze nadmořská výška a řád toku $[8,9]$, pro ryby úmoří, nadmořská výška a rád toku [6] a pro fytoplankton jen řád toku [10]. Naopak však bylo potřeba některé charakteristiky rozdělit detailněji to se týkalo hlavně fytobentosu [11], kde byly využity z typologie pouze nadmořská výška a řád toku, ale s mnohem vyšším počtem kategorií, popř. byly přidány další charakteristiky (např. pro makrozoobentos).

Úmoři tedy bylo nakonec využito pouze pro ryby, geologie pouze pro všeobecné fyzikálně-chemické ukazatele [12].

Porovnání důsledkư nastavení typologie $v$ prvním a druhém cyklu bylo možné jen pro fyzikálně-chemické ukazatele ekologického stavu.

Jak již bylo zmíněno, typově specifické podmínky umožňuji stanovit limity dobrého stavu pro skupiny typů rozdílně, což bylo použito jak v prvním, tak v druhém cyklu plánů.

Analýza nastavení limitů podle typů byla provedena pro čtyři ukazatele, které byly obdobně nebo stejně použity v obou cyklech a které výrazně ovlivnily výsledek ekologického stavu - dusičnanový dusík, celkový fosfor, rozpuštěný kyslík a biochemická spotřeba kyslíku. Přehled limitů dobrého stavu a charakteristických hodnot v prvním a druhém cyklu je uveden v tabulce 3 a 4.

Z porovnání obou tabulek vyplývá, že pro dusičnanový dusík byla sice změněna charakteristická hodnota z maxima na medián, ale zároveň střední hodnota byla zpřísněna, pro celkový fosfor došlo k výraznému zpřísnění, naopak pro rozpuštěný kyslík k výraznému změkčení a hodnocení BSK ${ }_{5}$ zůstalo stejné.

Pokud ovšem k limitům použijeme i faktor typologie, který změnil skupiny útvarů, pro které byl použit různě př́sný limit, celkový obraz se výrazně změní. Podíl útvarů s nejméně prísným limitem se pro dusičnanový dusík výrazně zvýšil (obr. 11 a 12), tudiž celkové hodnocení je mnohem mírnější (i bez zohlednění změny charakteristické hodnoty). Obdobně, i když pro celkový fosfor byly stanoveny tři přísnějš́ limity než v prvním cyklu, počet útvarů, na který se vztahovaly, byl natolik nízký (např. nejprísnější limit platil jen pro 4 útvary z 1044), že ve výsledku bylo zpřísnění minimální (obr. 13 a 14). Změkčení se potvrzuje pouze u rozpuštěného kyslíku, i když ne tak výrazně, jak by se mohlo zdát pouze z porovnání limitů (obr. 15 a 16). U biochemické spotřeby kyslíku sice zůstaly limity stejné, ale podíl útvarů s nejprísnější hodnotou klesl z 80 \% na 13 \% pro ČR (obr. 17 a 18).

\section{ZÁVĚRY A DISKUSE}

Z výsledků se ukazuje, že nastavení typologie dokáže ovlivnit cíle ochrany vod stejně výrazně jako nastavení hranice dobrého ekologického stavu. Pokud je prevládajících typů př́liš málo, nelze zodpovědně určit limit. Je pak pro značnou část útvarů zbytečně prísný nebo zbytečně mírný, popř. obojí. Stejně tak stanovení méně př́sných limitů má na první pohled méně viditelné nevýhody, např. v druhém cyklu plánů nevyhověla značná část útvarů kvůli biologickým složkám, ale protože související fyzikálně-chemické ukazatele byly vyhovující, nebylo možné racionálně navrhnout př́slušná opatření. Zároveň na evropské úrovni se objevuje snaha sjednotit značně rozdílné limity dobrého ekologického stavu, a to sice neurčením jednotných hodnot, ale harmonizací výsledku biologických složek a všeobecných fyzikálně-chemických ukazatelů: harmonizace hodnocení biologických složek na evropské úrovni už probíhá, a to procesem interkalibrace.

Určit správnost navržené typologie není bez ověření biologických a všeobecných fyzikálně-chemických ukazatelů možné, presto však již nyní je možné pochybovat, jestli byla typologie v druhém cyklu adekvátně nastavena. Zároveň ale nelze $v$ rámci třetího cyklu bez vyhodnocení následků zásadně pozměnit typologii, nebot’ by stejně jako v druhém cyklu mohla nastat situace, kdy výsledky hodnocení stavu nejdou vzhledem ke změnám metodik porovnávat, a tudíž chybí zpětná vazba týkající se efektivnosti navržených a provedených opatření. Měla by se tedy udělat analýza prínosů a nevýhod změn včetně důsledků v hodnocení ekologického stavu a podle toho citlivě zvážit úpravu typologie. 


\section{Literatura}

[1] Směrnice Evropského parlamentu a Rady 2000/60/ES ze dne 23. řijna 2000 ustavující rámec pro činnost Společenství v oblasti vodní politiky.

[2] LANGHAMMER, J. a kol. Vymezeni typů útvarů povrchových vod. Praha: Univerzita Karlova v Praze, Prírodovědecká fakulta, 2009.

[3] WFD Reporting Guidance 2016. Final draft, version 6. 0. 6 [online]. WFD CIS (Water Framework Directive's Common Implementation Strategy), 2016, [cit. 7. února 2017]. Dostupné z http://cdr.eionet. europa.eu/help/WFD/WFD_521_2016.

[4] European Environment Information and Observation Network (EIONET), Central Data Repository [online]. [cit. 7. února 2017]. Dostupné z: http://cdr.eionet.europa.eu/

[5] FUKSA, J.K. a PRCHALOVÁ, H. Vodní útvary v ČR. Výchozí vymezení vodních útvarů povrchových a podzemních vod a typologie vodních útvarů povrchových vod. Praha: VúV TGM, 2004.

[6] VúV TGM. Charakterizace oblastí povodí (Zpráva 2005).

[7] HORKÝ, P. Metodika hodnoceníekologického stavu útvarů povrchových vod tekoucích pomocíbiologické složky ryby. Praha: VúV TGM, 2011.

[8] HORKÝ, P. Metodika hodnoceniekologického stavu útvarů povrchových vod tekoucich pomocíbiologické složky makrozoobentos. Praha: VúV TGM, 2011.

[9] KOČí, M. a kol. Metodika hodnocení ekologického stavu útvarů povrchových vod tekoucích pomoc biologickésložky makrofyta. Praha: VúV TGM, 2011

[10] OPATR̈ILOVÁ, L. a kol. Metodika hodnocení ekologického stavu útvarů povrchových vod tekoucich pomocíbiologické složky fytoplankton. Praha: VÚV TGM, 2011.

[11] HORKÝ, P. Metodika hodnoceni ekologického stavu útvarů povrchových vod tekoucích pomocí biologickésložky fytobentos. Praha: VúV TGM, 2011.

[12] ROSENDORF, P. Metodika hodnoceni všeobecných fyzikálně-chemických složek ekologického stavu útvarů povrchových vod tekoucích. Praha: VúV TGM, 2011.

\section{Autoři}

RNDr. Hana Prchalová

凶hana.prchalova@vuv.cz

Mgr. Silvie Semerádová

凶silvie.semeradova@vuv.cz

\section{Ing. Petr Vyskoč}

凶petr.vyskoc@vuv.cz

Výzkumný ústav vodohospodářský T. G. Masaryka, v. v. i.

\section{SURFACE WATER BODY TYPOLOGY \\ CATEGORY RIVER IN THE ${ }^{\text {ST }}$ AND $2^{\text {ND }}$ \\ CYCLE OF RIVER BASIN MANAGEMENT \\ PLANS AND ITS CONSEQUENCE TO \\ ECOLOGICAL STATUS ASSESSMENT}

\section{PRCHALOVA, H.; SEMERADOVA, S.; VYSKOC, P.}

TGM Water Research Institute, p. r. i.

Keywords: Water Framework Directive - River Basin Management Plan - water body - surface water body typology - ecological status

Surface water body delineation and setting a typology are one of the initial steps during Water Framework Directive implementation (WFD) [1]. The first delineation and typology was prepared in 2004-2005 for the first plans, but all the results were significantly changed in the second cycle 2009-2010. River Basin Management Plans data processing enables obtain not only detailed summary of results, but also appreciates relations between partial results and their significance to achievement of specified objectives. The aim of the article is methods comparison in the $1^{\text {st }}$ and $2^{\text {nd }}$ cycle and draw the attention to changes consequence, affected the basic setting of surface water protection.

Příspěvek prošel lektorským řízením. 